\title{
Effect of conventional fertilization and integrated nutrient management in the Helichrysum orientale (L.) Vaill. (Asteraceae), a Greek native chasmophyte with ornamental and medicinal potential
}

\author{
G. Tsoktouridis ${ }^{1,2 *}$, I. Samartza1 ${ }^{1}$ E. Maloupa ${ }^{1}$ and N. Krigas ${ }^{1 *}$ \\ 1 Institute of Plant Breeding and Genetic Resources (IPBGR), Hellenic Agricultural \\ Organization (HAO) Demeter, Thessaloniki, Greece \\ ${ }^{2}$ THEOFRASTOS Fertilizers, Industrial Area of Korinthos, Greece \\ *Corresponding authors' email: gtsok1@yahoo.co.uk; nikoskrigas@gmail.com
}

\begin{abstract}
Helichrysum orientale (L.) Vaill. is a perennial wild-growing chasmophyte of the Eastern Mediterranean region, which shows great potential for utilization in floriculture, pharmacology and cosmetology. This research aimed to study the effect of conventional (chemical) fertilization and integrated nutrient management on the growth of specific characteristics of $\boldsymbol{H}$. orientale plants, after the natural flowering period of the species. The experiments were performed in pots (a) inside and (b) outside the greenhouse, (c) in the field and fertilization treatments were applied either on leaves or roots (foliar application/root application) or both. The parameters recorded were plant height, number of rosettes, fresh leaves' weight, dry leaves' weight, total fresh weight, and total dry weight. The results did not indicate many significant differences between treatments, however integrated nutrient management presented plants with the most desired attributes (rosettes' number, total fresh and dry weight, fresh leaves weight), some promoted by foliar application (first two) and others by root application (latter two). The results of this study can be utilized for the future establishment of a targeted protocol for the ex-situ cultivation of $\mathrm{H}$. orientale.
\end{abstract}

Keywords: Asteraceae, pot cultivation, field cultivation, greenhouse, floriculture, Greece

\section{INTRODUCTION}

The genus Helichrysum belongs to the plant family Asteraceae and consists of nearly 600 dwarf shrubs and herbs distributed worldwide (Akaberi et al., 2019). In Greece, the genus is represented by 13 taxa (species and subspecies) (Dimopoulos et al., 2016). The name of the genus originates from the Greek language, meaning sun (helios) and gold (chrisos) due to the often-bright yellow flowers (inflorescences) of Helichrysum members (Perrini et al., 2009). Helichrysum species usually grow on sunny, arid, rocky and sandy places (Leonardi et al., 2018).

Helichrysum plants are being used for over 2000 years for decoration and ornament, in traditional medicine and cosmetics, as well as in gastronomy (Akaberi et al., 2019). Many Helichrysum species have been utilized for decorative purposes for urban and domestic use, due to their impressive grey foliage and their bright or light-yellow capitulas 
(inflorescences). Also, these plants are tolerant of high temperatures and low water availability, and they can retain the bright color of their florets even after harvest, so dried flowers are also widely used in the floricultural industry as an ornamental plant. (Cervelli $e t$ al., 2012; Dragovic, 2005a, 2005b; Halevy, 2004, 2000). Helichrysum plants are also used in traditional medicine, as remedies for various ailments or as spice in food preparations (Akaberi et al., 2019). Several studies have highlighted the chemical properties of various Helichrysum species demonstrating their rich content in secondary metabolites and essential oils, suggesting that members of this genus could contribute to the discovery of new medicines (Akaberi et al., 2019). All agricultural systems are commonly use fertilization to provide adequate nutrition regimes to crop plants. Although chemical fertilizers are the most widely used form of fertilization, their environmental impact is high and therefore new methods are investigated to alleviate various related ecological problems, such as increased greenhouse gas emissions, high soil and water contamination or nutrient deficiency (Kakar et al., 2020). On the other side, integrated nutrient management is the combined use of chemical and organic fertilization and other biological factors aiming to limit the environmental cost and produce high quality crops at the same time (Gezahegn, 2021; Selim, 2020).

The target species of the current study is Helichrysum orientale (L.) Vaill., a perennial, wildgrowing chasmophyte on limestone sea cliffs, rocky slopes or walls with dense and hairy green-greyish foliage and greenish-yellow flowers (inflorescences), blooming from midApril to June. It is an Aegean subendemic plant of Greece found exclusively in the Aegean islands, Crete and on the western and southwestern coasts of Anatolia in Turkey (Hind et al., 2007, Strid 2016). In Greece, $H$. orientale is rarely available on the market as a flower plant for gardening and landscape architecture and is locally called 'amaranto' or 'semperviva' literally meaning everlasting ('stathouri' in Amorgos Island). $H$. orientale to date is excessively used for handmade creations and souvenirs in Kythera, Greece which are produced in a non-sustainable way by the locals, driving the wild-growing populations of this species at the verge of local extinction events. This study aims to investigate the cultivation potential of $H$. orientale by comparing the effect of conventional (chemical) fertilization and integrated nutrient management on the growth of specific plant characteristics. This approach offers new insight into the ex-situ cultivation, aiming to provide new information about the development of the plants for the sustainable use of the species in floriculture, pharmacology or cosmetics.

\section{MATERIALS AND METHODS}

Plant material and ex-situ maintenance in living collections. Wild-growing material of $H$. orientale was initially collected from wild-growing plants grown on rocky areas in the region of Lagada, Amorgos Island, Greece (Figure 1). All plant collections were performed using a special permit issued by the Greek ministry of Environment and Energy (Permit $82336 / 879$ of $18 / 5 / 2019 \& 26895 / 1527$ of $21 / 4 / 2021)$. After taxonomic identification, the unique IPEN (International Plant Exchange Network) accession number BBGK-15,5883 was assigned by the Institute of Plant Breeding and Genetic Resources (IPBGR) of the Hellenic Agricultural Organization Demeter. During the cold winter months, this mother plant material was maintained under special conditions at the Laboratory for the Conservation and Evaluation of Native and Floricultural Species - Balkan Botanic Garden of Kroussia (LCENFS - BBGK), Institute of Plant Breeding and Genetic Resources, Hellenic Agricultural Organization - Demeter (altitude $0 \mathrm{~m}$ ), using photoperiod lambs with $16 \mathrm{~h}$ light/ $8 \mathrm{~h}$ darkness and adjusted temperature higher than $10^{\circ} \mathrm{C}$. 

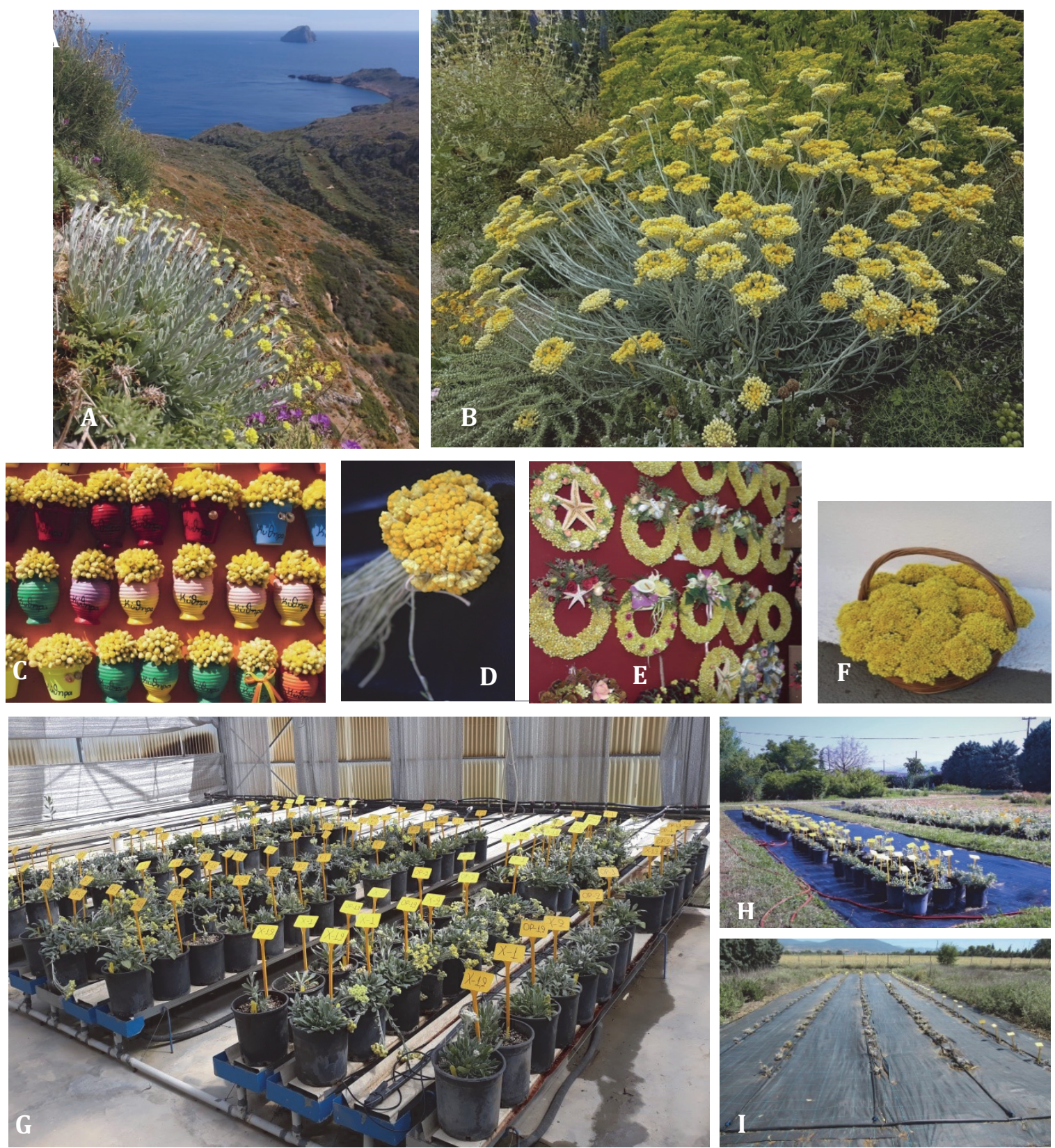

Figure 1. Top: Wild-growing Helichrysum orientale individuals in Kithira (A) and Amorgos Islands (B) of Greece (Photos: E. Dariotis). Middle: Souvenirs produced in Kithira (C, D) from harvested inflorescences by locals (E, F), Bottom: Sustainable cultivation of $H$ orientale in pots inside the greenhouse (G), in pots outside the greenhouse (H), and in the field (I) in Thessaloniki, northern Greece.

Later, the mother plants were pruned for protection against diseases and better ventilation. The vegetative propagation of mother plants utilized cuttings by using $0.2 \%$ Indole-3butyric acid (IBA; Racidin, Fytorgan ABEE) and then were transferred to the fog system with average temperature $19-25^{\circ} \mathrm{C}$ and relative humidity (RH) $70-85 \%$. After 20 days, the rooted $H$. orientale cuttings were transferred to $0.33 \mathrm{~L}$ pots under natural conditions and after one and a half month, the plants were transplanted to $1 \mathrm{~L}$ pots. Rooted plants were utilized for the experimentation of this research. 
Fertilization. In total, six treatments with liquid fertilizers and one control treatment were performed. Two types of fertilizations were applied: integrated nutrient management (INM) and chemical fertilization (CHF). Integrated nutrient management consisted of THEORUN fertilizer (Organic N fertilizer, THEOFRASTOS, Greece) at $5 \mathrm{~g} / \mathrm{L}$, THEOCAL fertilizer (Organic Ca fertilizer, THEOFRASTOS) at $1 \mathrm{~g} / \mathrm{L}, \mathrm{K}_{2} \mathrm{SO}_{4}$ (0-0-52, AGRI.FE.M. LTD Fertilizers, Greece) at $1.6 \mathrm{~g} / \mathrm{L}, \mathrm{MgSO}_{4}$ (Mg 25.6\%, AGRI.FE.M. LTD) at 0.32g/L, phosphorus (10-47-10, AGRI.FE.M. LTD) at $1 \mathrm{~g} / \mathrm{L}$ and trace elements (Plex Mix, AGRI.FE.M. LTD) at $1 \mathrm{ml} / \mathrm{L}$. Chemical fertilization consisted of $\mathrm{K}_{2} \mathrm{SO}_{4}$ (0-0-52, AGRI.FE.M. LTD) at 1.6g/L, $\mathrm{MgSO}_{4}$ (Mg 25.6\%, AGRI.FE.M. LTD) at $0.32 \mathrm{~g} / \mathrm{L}$, phosphorus (10-47-10, AGRI.FE.M. LTD) at $1 \mathrm{~g} / \mathrm{L}$, trace elements (Plex Mix, AGRI.FE.M. LTD) at $1 \mathrm{ml} / \mathrm{L}, \mathrm{NH}_{4} \mathrm{NO}_{3}$ (34.4-0-0, Neofert ${ }^{\circledR}$, Neochim PLC, Bulgaria) at $1.98 \mathrm{~g} / \mathrm{L}$ and $\mathrm{Ca}\left(\mathrm{NO}_{3}\right)_{2}$ (Ca 27\%, $\mathrm{N}$ 15.5\% NITROCAL, Agrohimiki, Greece) at $1.12 \mathrm{~g} / \mathrm{L}$. The fertilizers were administered by foliar application (treatments INM-FA, CHF-FA), root application (treatments INM-RA, CHF-RA) or a combination of both (treatments INM-FR, CHF-FR), so each management had three applications (Table 1). There was also one control treatment (C), in which tap water was applied on leaves and in rhizosphere. The amount of fertilizer used for foliar application depended on the size of each plant, whereas each plant needed $150 \mathrm{ml}$ of solution for root application. Fertilizations were performed once a week for three consecutive months (May to July).

Table 1. Applied fertilization treatments on Helichrysum orientale

\begin{tabular}{|c|c|c|}
\hline Treatment & Fertilization & Application \\
\hline INM-FA & Integrated nutrient management & Foliar \\
\hline INM-RA & Integrated nutrient management & Root \\
\hline INM-FR & Integrated nutrient management & Foliar and Root \\
\hline CHF-FA & Chemical fertilization & Foliar \\
\hline CHF-RA & Chemical fertilization & Root \\
\hline CHF-FR & Chemical fertilization & Foliar and Root \\
\hline C & Control (water) & Foliar and Root \\
\hline
\end{tabular}

Cultivation of $\boldsymbol{H}$. orientale in pots into the greenhouse. $H$. orientale rooted plants, propagated from mother material, were transplanted to $6 \mathrm{~L}$ pots for cultivation into the greenhouse (Figure 1). The soil substrate used, consisted of gold peat moss TS2 (Klasmann): perlite: river sand: black peat moss (Terrahum) at a ratio of 2:1:1:1 (Figure 1A). In total, six blocks were set up for the pilot cultivation of $H$. orientale in the greenhouse. Each block comprised of all seven treatments ( 6 blocks $\times 7$ treatments, in total 42 plants). Fertilization management was applied according to Table 1 . Irrigation of $H$. orientale plants was adapted to the plants' needs depending on the season (three times with $0.5 \mathrm{~L}$ of water in the dry season, once or twice in others).

Cultivation of $\mathrm{H}$. orientale in pots outside the greenhouse. Transplanted plants in $6 \mathrm{~L}$ pots in gold peat moss TS2 (Klasmann): perlite: river sand: black peat moss (Terrahum) at a ratio of 2:1:1:1 was used for this experiment. Pots were placed outside the greenhouse (Figure 1), at the nursery of LCENFS - BBGK (Thessaloniki, Greece) on a covered ground with geotextile plastic material (Figure 1B). For this experiment, 35 plants were used in total distributed in five blocks and each block had all seven treatments ( 5 blocks x 7 treatments). Fertilization and watering were applied as described above.

Cultivation of $\boldsymbol{H}$. orientale in the field. The pilot cultivation of $H$. orientale in the field took place in a specially designed plot, located at the LCENFS - BBGK (Thessaloniki, Greece), adjusted to the needs of this research. The whole plot was covered with black geotextile plastic material to reduce weeds' development. $H$. orientale plants were planted in elevated positions $(10-15 \mathrm{~cm})$ on the ground, in $80 \mathrm{~cm}$ rows and the plants were $\sim 40 \mathrm{~cm}$ far from 
each other (Figure 1C). In total, 173 plants were planted in the field. During plant establishment, the developed flowers of $H$. orientale were removed in order to observe new blossoming from the beginning of the experiment onwards. Plants cultivated in the field received further precautionary care with organophosphoric pesticides and fungicides (Admiral, Poleci, Trigramm, Dursban). Fertilization and watering of $H$. orientale in the field were performed as described previously.

Pre- and Post-harvest measurements. The measurements took place from May to September, and each week the shoot height of the plants was recorded. After the end of the experiments, the plants were dug and transferred to the lab of LCENFS - BBGK for further measurements. The plants' height, number of rosettes, fresh leaves weight and total fresh weight was recorded. Then, the plants were dried in a drying oven for 72 hours at $65^{\circ} \mathrm{C}$. Finally, dry leaves weight and total dry weight of the plants were estimated.

Statistical analysis of data. All three experiments were performed after the natural blooming period of $\mathrm{H}$. orientale, in a completely randomized design. In each experiment, seven treatments were tested with three replications each. Analysis of variance (ANOVA) was conducted using the statistical program SPSS 14.0 (SPSS Inc., Illinois, New York, USA) with significance level at $a=0.05(P \leq 0.05)$ and separation of means was performed according to Duncan's multiple comparison test.

\section{RESULTS AND DISCUSSION}

Helichrysum orientale is a perennial plant of Asteraceae presenting a remarkable prospect for crop utilization and it is cultivated herein in a pilot way. This research aims to first investigate the development of this species in out-of-season cultivation, after the natural flowering of the plants using integrated nutrient management techniques.

The pilot cultivation of $H$. orientale in pots inside and outside the greenhouse indicated some significant differences between treatments during the experimentation. In general, higher plants were observed in treatments inside the greenhouse with foliar application, and in chemical fertilization applied both on leaves and roots for plants outside the greenhouse (Table 2). The highest number of rosettes was recorded in plants cultivated inside the greenhouse that received both types of treatments, applied on the roots (Table 2). The greatest fresh and dry weight of leaves was shown in chemical fertilization applied on roots and in integrated nutrient management applied on leaves (Table 2). Finally, the highest total fresh weight was recorded for plants inside the greenhouse receiving chemical treatment with root application, and the highest total dry weight of plants was noted in integrated nutrient management with foliar application outside the greenhouse (Table 2).

The statistical analysis of these results did not indicate significant differences in most of the parameters recorded between treatments during the experimental period. However, total dry weight of plants was significantly different (ANOVA $P<0.05$ ) between treatments and experiments; integrated nutrient management applied on leaves (INM-FA) differed from other treatments in both experiments, inside and outside the greenhouse (Table 2). The treatment INM-FA in cultivation outside the greenhouse showed the highest total dry weight of $H$. orientale (Table 2). The total weight of dry leaves from all plants was recorded and analyzed too, regardless of treatment type. The results indicate that the total dry leaves weight differed significantly between plants cultivated inside and outside the greenhouse, with cultivation outside giving higher weight of dry leaves (Table 2).

The results from cultivation of plants in the field showed that the highest plants were observed in combined foliar and root applications in all treatments (Table 3). The number of rosettes was higher in chemical treatment applied on roots and in control treatment (Table 3). Also, the biggest fresh and dry weight of leaves and the biggest total fresh weight of 
plants were recorded in chemical fertilization by root application (Table 3). Finally, the total dry weight of plants was higher in chemical treatment applied either on roots or both on leaves and roots (Table 3). Fresh and dry total plant weight showed significant differences between treatments with ANOVA $P<0.05$ and chemical fertilization led to better results than integrated nutrient management (Table 3 ).

The current research aimed to investigate for the first time the sustainable exploitation of $H$. orientale in cultivation inside and outside the greenhouse or in the field after the end of the natural flowering of the plant, using two different types of fertilization and three types of application. The different fertilizations applied differed regarding the organic $\mathrm{N}$, organic $\mathrm{Ca}$, $\mathrm{NH}_{4} \mathrm{NO}_{3}$, and $\mathrm{Ca}\left(\mathrm{NO}_{3}\right)_{2}$ content. The specific parameters recorded during the experimentation, e.g., plant height, number of rosettes, fresh leaves weight, dry leaves weight, total fresh weight, total dry weight, are important for the utilization of $H$. orientale in floriculture and/or pharmacology. Specifically, the plant height and number of rosettes are most significant for ornamental purposes, whereas fresh and dry leaves weight and total fresh and dry weight are mostly considered important when the plant is used for its chemical properties.

Table 2. Results of the pilot cultivation of Helichrysum orientale in pots inside (IN) and outside (OUT) the greenhouse in Thessaloniki with chemical fertilization (CHF) and integrated nutrient management (INM) either by foliar application (FA) or root application (RA) or combined foliar and root application (FR). Control (C) with combined foliar and root application only with water.

\begin{tabular}{|c|c|c|c|c|c|c|c|c|}
\hline \multirow[t]{2}{*}{ PARAMETERS } & \multirow[t]{2}{*}{ EXPERIMENT } & \multicolumn{7}{|c|}{ TREATMENTS } \\
\hline & & $\begin{array}{c}\text { CHF- } \\
\text { FA }\end{array}$ & $\begin{array}{c}\text { CHF- } \\
\text { RA }\end{array}$ & $\begin{array}{c}\text { CHF- } \\
\text { FR }\end{array}$ & $\begin{array}{l}\text { INM- } \\
\text { FA }\end{array}$ & $\begin{array}{c}\text { INM- } \\
\text { RA }\end{array}$ & $\begin{array}{l}\text { INM- } \\
\text { FR }\end{array}$ & $\mathbf{C}$ \\
\hline \multirow[t]{2}{*}{ Plant height ${ }^{1}(\mathrm{~cm})$} & IN & 8.00 & 6.33 & 7.67 & 7.67 & 7.00 & 5.67 & 6.67 \\
\hline & OUT & 5.83 & 6.83 & 10.17 & 7.33 & 6.67 & 7.00 & 7.17 \\
\hline \multirow[t]{2}{*}{ Rosettes number ${ }^{2}$} & IN & 26.67 & 30.67 & 21.33 & 21.00 & 31.00 & 23.67 & 8.67 \\
\hline & OUT & 16.67 & 20.00 & 19.33 & 28.00 & 16.67 & 19.67 & 17.00 \\
\hline \multirow{2}{*}{$\begin{array}{c}\text { Fresh leaves } \\
\text { weight }^{3}(\mathrm{~g})\end{array}$} & IN & 10.17 & 13.92 & 7.77 & 9.47 & 12.72 & 11.31 & 4.55 \\
\hline & OUT & 10.48 & 13.90 & 13.21 & 16.34 & 13.35 & 12.83 & 9.06 \\
\hline \multirow{2}{*}{$\begin{array}{c}\text { Dry leaves weight } \\
\text { (g) }\end{array}$} & IN & 3.21 & 3.50 & 2.33 & 3.29 & 3.98 & 2.86 & 1.59 \\
\hline & OUT & 4.02 & 4.94 & 3.93 & 4.82 & 4.28 & 3.76 & 3.66 \\
\hline \multirow{2}{*}{$\begin{array}{c}\text { Total fresh weight }{ }^{5} \\
\text { (g) }\end{array}$} & IN & 16.67 & 18.45 & 15.27 & 13.39 & 25.61 & 18.89 & 7.14 \\
\hline & OUT & 13.05 & 18.03 & 16.46 & 21.60 & 16.00 & 16.65 & 12.79 \\
\hline \multirow{2}{*}{$\begin{array}{c}\text { Total dry } \\
\text { weight }^{6}(\mathrm{~g})\end{array}$} & IN & 5.13 & 5.77 & 5.08 & $5.04 \mathrm{a}$ & 7.82 & 4.66 & 2.74 \\
\hline & OUT & 5.32 & 7.08 & 6.31 & $\begin{array}{c}10.12 \\
b\end{array}$ & 5.80 & 5.88 & 5.48 \\
\hline \multirow{2}{*}{$\begin{array}{c}\text { Total dry leaves } \\
\text { weight }^{7}(\mathrm{~g})\end{array}$} & IN & \multicolumn{7}{|c|}{$5.176 \mathrm{a}$} \\
\hline & OUT & \multicolumn{7}{|c|}{$6.568 \mathrm{~b}$} \\
\hline
\end{tabular}

Mean numbers of a Completely Random Designed experiment with seven treatments and three replications, compared using Duncan's' multiple comparisons test (SPSS 14.0, ANOVA, P $\leq 0,05) .1$ Standard Errors (SES) - 1SE: 1,473 / ${ }^{2} S E: 7,673 /{ }^{3} S E: 2,938 /{ }^{4} S E: 0,82 /{ }^{5} S E: 4,735 /{ }^{6 S E}: 1,366 /{ }^{7} S E: 1,932$

Even though these results do not indicate a complete pattern after one cultivation period, they can provide information when it comes to determining the conditions and fertilization status of $H$. orientale cultivation for a certain purpose (see Figure 2). In general, it appears that comparatively better results can be obtained from cultivation of $H$. orientale in pots or in the greenhouse, rather than cultivation in the field (Figure 2). This could be due to a variety of reasons, such as unstable outdoor environmental conditions, varied temperatures 
and greater threat by weeds and microorganisms that these plant individuals may face in the field.

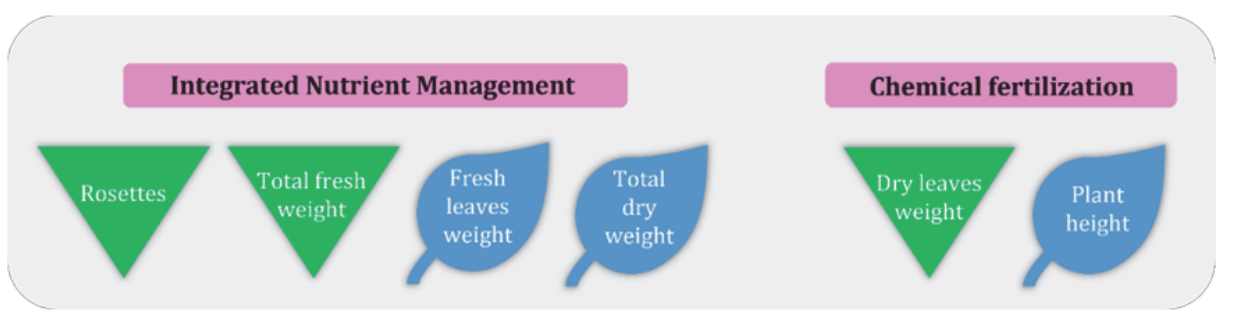

Figure 2. Best treatments for the cultivation of $H$. orientale detected after integrated nutrient management and chemical fertilization by foliar and/or root applications. Leaf: Foliar application;

Triangle: Root application, Blue: in pots outside greenhouse, Green: in pots inside greenhouse.

Table 3. Results of the pilot cultivation of Helichrysum orientale in the field with chemical fertilization (CHF) and integrated nutrient management (INM) either by foliar application (FA) or root application

(RA) or combined foliar and root application (FR). Control treatment (C) included combined foliar and root application only with water.

\begin{tabular}{|c|c|c|c|c|c|c|c|}
\hline \multirow{2}{*}{ PARAMETERS } & \multicolumn{9}{|c|}{ TREATMENTS } \\
\cline { 2 - 8 } & CHF-FA & CHF-RA & CHF-FR & INM-FA & INM-RA & INM-FR & C \\
\hline \multirow{2}{*}{ Plant height (cm) } & $\begin{array}{c}8.20 \\
\pm 1.70\end{array}$ & $\begin{array}{c}8.17 \\
\pm 2.00\end{array}$ & $\begin{array}{c}9.67 \\
\pm 1.40\end{array}$ & $\begin{array}{c}7.83 \\
\pm 1.80\end{array}$ & $\begin{array}{c}6.60 \\
\pm 1.30\end{array}$ & $\begin{array}{c}9.50 \\
\pm 2.60\end{array}$ & $\begin{array}{c}8.40 \\
\pm 0.80\end{array}$ \\
\hline Rosettes number & $\begin{array}{c}12.67 \\
\pm 3.20\end{array}$ & $\begin{array}{c}18.67 \\
\pm 5.20\end{array}$ & $\begin{array}{c}15.67 \\
\pm 3.90\end{array}$ & $\begin{array}{c}9.67 \\
\pm 3.30\end{array}$ & $\begin{array}{c}13.67 \\
\pm 3.70\end{array}$ & $\begin{array}{c}14.67 \\
\pm 1.20\end{array}$ & $\begin{array}{l}20.33 \\
\pm 1.20\end{array}$ \\
\hline Fresh leaves weight & $\begin{array}{c}3.42 \\
\text { (g) }\end{array}$ & $\begin{array}{c}5.26 \\
\pm 1.00 \mathrm{abc}\end{array}$ & $\begin{array}{c}4.30 \\
\pm 0.20 \mathrm{ab}\end{array}$ & $\begin{array}{c}1.82 \\
\pm 0.30 \mathrm{c}\end{array}$ & $\begin{array}{c}2.50 \\
\pm 0.80 \mathrm{bc}\end{array}$ & $\begin{array}{c}3.57 \\
\pm 0.30 \mathrm{abc}\end{array}$ & $\begin{array}{c}3.22 \\
\pm 0.40 \mathrm{abc}\end{array}$ \\
\hline $\begin{array}{c}\text { Dry leaves weight } \\
\text { (g) }\end{array}$ & $\begin{array}{c}1.38 \\
\pm 0.42 \mathrm{abc}\end{array}$ & $\begin{array}{c}1.95 \\
\pm 0.51 \mathrm{a}\end{array}$ & $\begin{array}{c}1.79 \\
\pm 0.11 \mathrm{ab}\end{array}$ & $\begin{array}{c}0.79 \\
\pm 0.15 \mathrm{c}\end{array}$ & $\begin{array}{c}0.99 \\
\pm 0.30 \mathrm{bc}\end{array}$ & $\begin{array}{c}1.45 \\
\pm 0.12 \mathrm{abc}\end{array}$ & $\begin{array}{c}1.39 \\
\pm 0.22 \mathrm{abc}\end{array}$ \\
\hline $\begin{array}{c}\text { Total fresh weight } \\
\text { (g) }\end{array}$ & $\begin{array}{c}7.20 \\
\pm 1.06 \mathrm{ab}\end{array}$ & $\begin{array}{c}8.43 \\
\pm 0.94 \mathrm{a}\end{array}$ & $\begin{array}{c}7.52 \\
\pm 0.12 \mathrm{ab}\end{array}$ & $\begin{array}{c}4.94 \\
\pm 0.29 \mathrm{c}\end{array}$ & $\begin{array}{c}6.15 \\
\pm 0.16 \mathrm{bc}\end{array}$ & $\begin{array}{c}6.80 \\
\pm 0.38 \mathrm{ab}\end{array}$ & $\begin{array}{c}7.02 \\
\pm 0.32 \mathrm{ab}\end{array}$ \\
\hline Total dry weight (g) & $\begin{array}{c}3.38 \\
\pm 0.30 \mathrm{ab}\end{array}$ & $\begin{array}{c}3.85 \\
\pm 0.55 \mathrm{a}\end{array}$ & $\begin{array}{c}3.86 \\
\pm 0.09 \mathrm{a}\end{array}$ & $\begin{array}{c}2.64 \\
\pm 0.15 \mathrm{bc}\end{array}$ & $\begin{array}{c}2.30 \\
\pm 0.51 \mathrm{c}\end{array}$ & $\begin{array}{c}3.27 \\
\pm 0.19 \mathrm{abc}\end{array}$ & $\begin{array}{c}3.46 \\
\pm 0.09 \mathrm{ab}\end{array}$ \\
\hline
\end{tabular}

Mean numbers and Standard Errors of a Completely Random Designed experiment with seven treatments and three replications, compared using Duncans' multiple comparisons test (SPSS 14.0, ANOVA, P $\leq 0,05$ ).

Also, integrated nutrient management led to better development of more parameters compared to chemical fertilization (Figure 2). Papaforiou et al. $(2018,2013)$ investigating the growth of several aromatic Mediterranean xerophytes on green roofs (including $H$. orientale) reported the effect of substrate type on plant growth, and outlined that compostmodified substrate provides similar or better results than peat substrate, thus indicating the effect of organic material on plant growth (Papafotiou et al., 2018; Papafotiou and Adami, 2013). The results of the current study give insight to the needs of $H$. orientale in ex-situ cultivation and can be used for further research in order to establish a targeted protocol for the sustainable utilization of this ornamental and medicinal species.

\section{CONCLUSIONS}

In conclusion, the cultivation of $H$. orientale was more successful in pots inside and outside the greenhouse than in the field. Both integrated nutrient management and chemical fertilization promoted the plant's growth, with the latter being more efficient, and the best application of treatments were foliar and root, while combined application was not that 
effective. These results can be used for the cultivation of $H$. orientale in order to trigger the development of specific characteristics, but further research needs to be done to create a targeted protocol for the cultivation of this species.

\section{ACKNOWLEDGEMENTS}

The authors would like to thank Christina Moutsaki and Georgios Tsiaparas for their technical participation in the current study, Dr Anna Nikolaidou for the statistical analysis of data and the staff of the Institute of Plant Breeding and Genetic Resources, Hellenic Agricultural Organization Demeter for administrative and technical support.

\section{REFERENCES}

1. Akaberi, M., Sahebkar, A., Azizi, N., and Emami, S.A., (2019). Everlasting flowers: Phytochemistry and pharmacology of the genus Helichrysum. Ind. Crops Prod. 138, 111471. https://doi.org/10.1016/j.indcrop.2019.111471

2. Cervelli, C., Farina, E., Dalla Guda, C., Giovannini, A., Liotta, A., Paterniani, T., Burchi, G., Cacini, S., Antonetti, M., Zizzo, G., and Aprile, S., (2012). Development of new ornamental plants and germplasm selection in Mediterranean native species. Acta Hortic. 937, 45-50. https://doi.org/10.17660/ActaHortic.2012.937.3

3. Dimopoulos, P., Raus, T., Bergmeier, E., Constantinidis, T., Gregoris, I., Kokkini, S., Strid, A., and Tzanoudakis, D., (2016). Vascular plants of Greece: An annotated checklist. Supplement. Willdenowia 46, 301-347. https://doi.org/10.3372/wi.46.46303

4. Dragovic, M.J.O., (2005a). Flowering behavior of Helichrysum obconicum DC. Acta Hortic. 683, $357-361$. https://doi.org/10.17660/actahortic.2005.683.45

5. Dragovic, M.J.O., (2005b). Utilization of Helichrysum devium Johns. and Helichrysum obconicum DC. as ornamental plants. Acta Hortic. 683, 181-187. https://doi.org/10.17660/ActaHortic.2005.683.20

6. Gezahegn, A., (2021). Role of integrated nutrient management for sustainable maize production. Int. J. Agron. 2021, 1-7. https://doi.org/10.1155/2021/9982884

7. Halevy, A.H., (2004). The use of native Israeli flora for introduction of new ornamental crops. Acta Hortic. 598, 55-58. https://doi.org/10.17660/ActaHortic.2003.598.6

8. Halevy, A.H., (2000). Introduction of native Israeli plants as new cut flowers. Acta Hortic. 541, 79-82. https://doi.org/10.17660/ActaHortic.2000.541.10

9. Hind, N., Strange, K., and Broome, J., (2007). Helichrysum orientale: Compositae. Curtis's Bot. Mag. 24, $251-259$. https://doi.org/10.1111/j.1467-8748.2007.00602.x

10. Kakar, K., Dang Xuan, T., Noori, Z., Aryan, S., and Gulab, G., (2020). Effects of organic and inorganic fertilizer application on growth, yield, and grain quality of rice. Agriculture 10, 544. https://doi.org/10.3390/agriculture10110544

11. Leonardi, M., Giovanelli, S., Ambryszewska, K.E., Ruffoni, B., Cervelli, C., Pistelli, La., Flamini, G., and Pistelli, Lu., (2018). Essential oil composition of six Helichrysum species grown in Italy. Biochem. Syst. Ecol. 79, 15-20. https://doi.org/10.1016/j.bse.2018.04.014

12. Papafotiou, M., and Adami, I., (2013). Growth of golden oregano on an urban extensive green roof as affected by substrate type and irrigation frequency. Acta Hortic. 1298, 569-574. https://doi.org/10.17660/ActaHortic.2020.1298.78

13. Papafotiou, M., Tassoula, L., and Mellos, K., (2018). Construction and maintenance factors affecting most the growth of shrubby Mediterranean native plants on urban extensive green roofs. Acta Hortic. 1215, 101107. https://doi.org/10.17660/ActaHortic.2018.1215.18

14. Perrini, R., Morone-Fortunato, I., Lorusso, E., and Avato, P., (2009). Glands, essential oils and in vitro establishment of Helichrysum italicum (Roth) G. Don ssp. microphyllum (Willd.) Nyman. Ind. Crops Prod. 29, 395-403. https://doi.org/10.1016/j.indcrop.2008.07.010

15. Selim, M., (2020). Introduction to the Integrated Nutrient Management Strategies and Their Contribution to Yield and Soil Properties. Int. J. Agron. 2020, 1-14. https://doi.org/10.1155/2020/2821678

16. Strid, A., (2016). Atlas of the Aegean Flora. Botanic Garden and Botanical Museum Berlin-Dahlem, (Berlin: BGBM Press online shop), Englera g33 (2 parts). ISBN 978-3-921800-97-3 (part 1); 978-3-921800-98-0 (part 2). 